\title{
Penghapusan Paten Terdaftar di Indonesia: Perkembangan dan Penyebabnya
}

\author{
Alif Muhammad Ardani \\ Fakultas Hukum Universitas Jambi \\ alifardani39@gmail.com
}

\begin{abstract}
This article discusses the cancellation or revocation of patents registered in Indonesia and their causes. Revocation or cancellation of a patent is a form of law enforcement of patents that have been registered, because the invention given a patent is not eligible for a patent or the patent owner does not carry out his obligations. With a revocation, the exclusive right of the inventor or patent holder to use his invention will be lost. The results showed, first, the revocation of patents so far was dominated by patents and not simple patents, and most of them were from abroad. However, this fact does not mean that domestic patents are far more applicable or more compliant with statutory provisions, but it must also be related that the number of patents registered in Indonesia so far is mostly from abroad. Second, the revocation of patents was dominated by patent holders who do not carry out patent maintenance fees. This is because patents that have been registered are considered unproductive so it is difficult to apply in the industry; research development that requires a large enough cost so that it results in accumulation of patent maintenance payments; and the transition of provisions regarding the cost and maintenance period of patents from the old Patent Law (2001) to the new Law (2016) which is relatively unknown.
\end{abstract}

Keywords: patent; cancellation; revocation; maintenance fee 


\section{Abstrak}

Artikel ini membahas perkembangan pembatalan atau penghapusan paten terdaftar di Indonesia beserta faktor yang menyebabkannya. Penghapusan atau pembatalan paten merupakan suatu bentuk penegakan hukum terhadap paten yang sudah terdaftar, disebabkan invensi yang diberi paten tidak layak mendapatkan paten atau pemilik paten tidak melaksanakan kewajibannya. Dengan pembatalan atau penghapusan, maka hak eksklusif inventor atau pemegang paten untuk menggunakan invensinya akan menjadi hilang. Hasil penelitian menunjukkan, pertama, pembatalan atau penghapusan paten terdaftar sejauh ini didominasi pada paten dan bukan paten sederhana, dan sebagian besar berasal dari luar negeri. Namun demikian fakta ini tidak berarti bahwa paten dalam negeri jauh lebih aplikatif atau lebih mematuhi ketentuan peraturan perundang-undangan, melainkan juga harus dikaitkan bahwa jumlah paten terdaftar di Indonesia sejauh ini memang sebagian besar berasal dari luar negeri. Kedua, penghapusan paten terdaftar didominasi oleh pemegang paten yang tidak melakukan biaya pemeliharaan paten. Hal ini bisa jadi disebabkan oleh paten yang telah terdaftar dinilai tidak produktif sehingga sulit diterapkan dalam industri; pengembangan riset yang memerlukan biaya yang cukup besar sehingga mengakibatkan akumulasi pembayaran pemeliharaan paten; dan peralihan ketentuan mengenai biaya dan masa pemeliharaan paten dari UU Paten lama (Tahun 2001) ke UU baru (Tahun 2016) yang relatif belum dipahami.

Kata Kunci: paten; pembatalan; penghapusan; biaya pemeliharaan

\section{A. Pendahuluan}

Artikel ini membahas perkembangan penghapusan paten terdaftar di Indonesia dan faktor yang menyebabkannya. Penghapusan paten terdaftar sendiri merupakan suatu bentuk penegakan hukum terhadap paten yang sudah diberikan atau paten terdaftar untuk selanjutnya dihapuskan dari daftar paten terdaftar. Penghapusan demikian membawa konsekuensi hilangnya akibat hukum yang berkaitan dengan paten atau yang berasal dari paten terdaftar. Hak eksklusif untuk menggunakan suatu invensi yang didapat inventor sebagai imbalan atas diperolehnya paten atas invensi tersebut, akan menjadi hilang begitu paten tersebut dihapuskan dari daftar paten 
terdaftar.

Pembahasan penghapusan paten ini penting dilakukan setidaknya karena tiga alasan. Pertama, paten sesungguhnya hak keperdataan dalam hal ini hak kebendaan ${ }^{1}$ yang diperoleh dengan syarat yang relatif sulit, termasuk dibanding dengan bidang kekayaan intelektual lainnya. Syarat baru, mengandung langkah inventif, dan dapat diterapkan dalam industri, merupakan syarat yang relatif hanya bisa dipenuhi oleh orang-orang yang melakukan penelitian dengan inovatif dan kreatif. Oleh karenanya, akan menimbulkan pertanyaan, mengapa ketika invensi sudah diberi paten justru kemudian menjadi dihapuskan.

Kedua, penghapusan paten terdaftar hanya bisa dilakukan karena empat hal: permohonan dari pemegang paten dan dikabulkan oleh Menteri, putusan pengadilan yang berkekuatan hukum tetap, putusan Komisi Banding Paten, dan tidak terpenuhinya kewajiban pemilik atau pemegang paten membayar biaya tahunan. ${ }^{2}$ Di antara empat sebab penghapusan tersebut, jika ditelisik lebih lanjut maka sebagian besarnya disebabkan karena "invensi yang diberi paten tidak layak mendapatkan paten" atau "pemilik paten tidak melaksanakan kewajibannya". Dalam hal pemilik paten tidak melaksanakan kewajibannya, maka hal ini menjadi pertanyaan tentang maksud pemilik

1 Hak kebendaan atau zakelijk recht adalah hak mutlak atas suatu benda yang memberikan kekuasaan langsung atas suatu benda dan dapat dipertahankan terhadap siapapun juga. Dalam hak keperdataan, selain hak kebendaan juga terdapat lawannya yaitu hak perorangan (persoonlijk recht). Hak kebendaan sendiri mempunyai ciri-ciri unggulan, antara lain bersifat mutlak, asas droit de suite, asas prioritas, asas droit de preference, dan gugat kebendaan. Trisadini Prasastinah Usanti, "Lahirnya Hak Kebendaan”, Perspektif: Kajian Masalah Hukum dan Pembangunan, 17, 1 (2012): 44-53. Digolongkannya paten dan juga bidang hak kekayaan intelektual lainnya sebagai hak kebendaan atau hukum harta kebendaan adalah karena hak-hak (HKI) tersebut memiliki sifat-sifat hak-hak kebendaan dan dapat dimiliki secara absolut (hak mutlak). Ia memiliki ciri: dapat dijual, dilisensikan, diwariskan, dan lain-lainnya sehingga dapat dipindahtangankan kepemilikannya berdasarkan alasan yang sah dan dapat dibenarkan menurut hukum seperti hak kebendaan lainnya. Lihat: Dadan Syamsudin, "Hak Kekayaan Intelektual dan Manfaatnya Bagi Lembaga Litbang”, http://sumberdaya.ristekdikti.go.id/wp-content/ uploads/2016/11/Makalah-HKI-dadan.pdf, diakses 10/6/2019.

2 UU No. 13 Tahun 2016 tentang Paten, Pasal 130. 
paten mendaftarkan paten, sebab kewajiban tersebut sesungguhnya menjadi imbangan atas hak yang diperoleh. Jika hak pemilik paten adalah mendapat hak eksklusif dalam melaksanakan paten, maka kewajibannya ialah melaksanakan invensinya di Indonesia $^{3}$ dan membayar biaya tahunan.

Ketiga, penghapusan paten, atau yang sebelumnya disebut dengan pembatalan paten, masih terus berlangsung bahkan dalam tahun tertentu, sebagaimana nanti terlihat dalam pembahasan, cenderung meningkat. Oleh karenanya penting untuk diteliti apa gerangan yang menyebabkannya. Pembahasan tentang sebab penghapusan paten yang terjadi selama ini akan turut menjelaskan tentang realita perlindungan paten di Indonesia sejauh ini, yang sering disorot tertutama karena rendahnya invensi dalam negeri yang mendapat paten.

Pembahasan artikel ini didasarkan pada data primer dan sekunder. Data primer diperoleh dan diolah dari Direktorat Jenderal (Ditjen) Kekayaan Intelektual (KI) Kementerian Hukum dan Hak Asasi Manusia (Kemenkumham), baik itu yang sifatnya kuantitatif berupa data pembatalan dan penghapusan paten maupun yang kualitatif berupa keterangan dari pejabat atau staff yang berkompeten. Data sekunder dalam artikel ini diperoleh dari artikel, buku, atau laporan yang terkait dengan paten pada umumnya.

Dalam menjelaskan perkembangan dan sebab penghapusan paten, artikel ini setelah bagian ini menguraikan terlebih dahulu paten dan invensi yang diberi paten. Bagian selanjutnya membahas paten-invensi dan hak-kewajiban pemegang paten. Bagian berikutnya memaparkan perkembangan penghapusan paten dan dilanjutkan dengan pembahasan sebab-sebab penghapusan paten.

3 Kewajiban melaksanakan invensi di Indonesia bagi inventor atau pemegang paten ini pada dasarnya dimaksudkan untuk mengembangkan sekaligus meningkatkan industri di dalam negeri. Pengembangan dan peningkatan industri dalam negeri, atau disebut dengan industrialisasi, merupakan bagian dari politik hukum dibentuknya UU Paten di Indonesia. Lebih jauh baca: M. Zulfa Aulia, "Politik Hukum Pembentukan UU Paten di Indonesia: Industrialisasi, Liberalisasi, dan Harmonisasi”, Jurnal Hukum Ius Quia Iustum, 22, 2 (2015): 223-237. 


\section{B. Paten dan Invensi}

Secara etimologi kata "paten" berasal dari patent (bahasa inggris), yang awalnya berasal dari kata patere yang berarti membuka diri atau "terbuka". Lawan katanya adalah "laten" yang berarti "tersembunyi/ terselubung”. Konsep terbuka dimaksudkan bahwa inventor membuka pengetahuan dan teknologi yang dimiliki guna kemajuan masyarakat dan sebagai gantinya, inventor mendapatkan hak eksklusif selama periode tertentu. ${ }^{4}$ Menurut Kamus Hukum, paten atau yang biasa disebut dengan octrooi adalah "hak yang diberikan kepada seseorang atas permohonannya untuk menikmati sendiri hasil penemuannya dan sebagai perlindungan terhadap kemungkinan adanya peniruan terhadap hasil ciptaannya/ penemuannya itu."

Sedangkan menurut Undang-Undang Nomor 13 Tahun 2016 (UU Paten Tahun 2016), paten adalah hak eksklusif atas hasil invensinya di bidang teknologi. Penggunaan kata invensi lebih tepat mengingat maknanya sebagai perancangan sesuatu yang sebelumnya tidak ada. Invensi yang dimaksud yaitu di bidang teknologi. Teknologi adalah cara atau metode serta proses produk yang dihasilkan dari penerapan dan pemanfaatan berbagai displin ilmu pengetahuan yang menghasilkan nilai bagi pemenuhan kebutuhan kelangsungan dan peningkatan mutu kehidupan manusia. Teknologi ini lahir dari hasil olah pikir dan intelektualitas manusia dengan segala pengorbanannya baik waktu, tenaga, biaya sehingga mempunyai nilai ekonomi yang dapat dijadikan kekayaan bagi pemilik teknologi. ${ }^{6}$

UU Paten membedakan antara paten dan paten sederhana.

4 Slamet Yuwanto, Memahami Paten (Bandung: Keni Media, 2017), hlm. 1. "Buka" atau "terbuka" di sini juga mengandung maksud bahwa suatu penemuan atau invensi yang mendapatkan paten menjadi terbuka untuk diketahui oleh umum. Lihat: Muhammad Djumhana dan R. Djubaedillah, Hak Milik Intelektual: Sejarah, Teori, dan Prakteknya di Indonesia (Bandung: Citra Aditya Bakti, 1997), hlm. 110.

5 Rudyat, Charlie. Kamus Hukum (Yogyakarta: Pustaka Mahardika, 2016).

6 Yuwanto, Memahami Paten, hlm. 5. Teknologi sendiri dapat dikelompokkan ke dalam tiga bagian. Pertama, teknologi sebagai barang buatan, teknologi sebagai kegiatan manusia, dan teknologi sebagai kumpulan pengetahuan. Lihat: Ridwan Khairandy, Hukum Alih Teknologi (Yogyakarta: Fakultas Hukum Universitas Islam Indonesia, 1995), hlm. 90. 
Perbedaan di antara keduanya adalah, paten diberikan untuk invensi yang mengandung kebaruan, langkah inventif (inventive step), dan dapat diterapkan dalam industri. Sedangkan paten sederhana diberikan untuk invensi yang baru namun bisa berupa pengembangan proses dari produk atau proses yang telah ada, serta dapat diterapkan dalam industri.

Berdasarkan Pasal 3 ayat (1) jo. Pasal 2 huruf a UU Paten Tahun 2016, pemberian paten dapat dilakukan dengan persyaratan, pertama, invensi harus baru (novelty). Suatu invensi dapat dikatakan baru jika tidak didahului pengetahuan dan kecakapan terdahulu (prior art). Penemuan terdahulu adalah penemuan dan segala bentuk informasi yang terkait dengan penemuan tersebut yang telah ada sebelum penemuan yang bersangkutan diajukan permintaan paten atau sebelum tanggal pengajuan permintaan paten yang bersangkutan. Invensi yang baru juga diartikan sebagai invensi tersebut tidak sama dengan teknologi yang telah pernah diungkap atau didaftarkan sebelumnya.

Kedua, mengandung langkah inventif. Invensi dikatakan mengandung langkah inventif jika invensi tersebut bagi seseorang yang mempunyai keahlian tertentu di bidang teknik merupakan suatu hal yang tidak dapat diduga sebelumnya. Ketiga, dapat diterapkan dalam industri. Invensi dapat diterapkan dalam industri jika invensi tersebut dapat dilaksanakan dalam industri sebagaimana diuraikan dalam permohonan. Invensi berupa produk yang dapat diterapkan dalam industri harus mampu dibuat secara berulang-ulang (secara massal) dengan kualitas dan produk yang sama, sedangkan jika invensi berupa proses maka proses tersebut harus mampu dijalankan atau digunakan dalam praktik.

UU Paten juga mengatur tentang invensi yang tidak dapat diberi paten, yaitu:

1. Proses atau produk yang pengumuman, penggunaan atau pelaksanaannya bertentangan dengan peraturan perundang-undangan, agama, ketertiban umum, atau kesusilaan;

2. Metode pemeriksaan, perawatan, pengobatan dan atau pembedahan yang diterapkan terhadap manusia dan/atau hewan;

3. Teori dan metode di bidang ilmu pengetahuan dan matematika; 
4. Makhluk hidup, kecuali jasad renik; atau

5. Proses biologi yang esensial untuk memproduksi tanaman atau hewan, kecuali proses non-biologis atau proses mikrobiologis.

Dalam sistem pendaftaran paten, bentukpemberian paten setelah invensi memenuhi syarat tertentu disebut dengan sistem konstitutif. Dengan sistem konstitutif, maka suatu paten yang hendak didaftarkan akan diselidiki terlebih dahulu memenuhi syarat substantifnya atau tidak, dan apabila memenuhi baru diberikan paten. ${ }^{7}$

Pergerakan globalisasi yang begitu pesat menimbulkan kesadaran bagi seorang penemu (inventor) guna melindungi hasil penemuannya (invensi) dengan tujuan untuk mendapatkan perlindungan, meningkatkan daya saing masyarakat dan mencari keuntungan dari nilai ekonomi pada suatu karya yang dihasilkan. Invensi di bidang teknologi memberikan dampak yang signifikan terhadap kesejahteraan masyarakat. ${ }^{8}$ Suatu invensi yang dihasilkan mempunyai nilai ekonomis dan mendapatkan perlindungan apabila invensi tersebut telah dipatenkan. Oleh karenanya, perlindungan paten, juga HKI pada umumnya, dapat dikatakan sebagai kebutuhan fitrah manusia, yaitu kebutuhan untuk mendapatkan penghargaan atas sesuatu yang dimiliki atau telah dihasilkannya, dan kemandirian di bidang ekonomi. ${ }^{9}$

7 Sebagai kebalikan atau lawan sistem konstitutif, juga dikenali sistem deklaratif atau declaratoir. Dalam sistem declaratoir, setiap paten yang telah memenuhi persyaratan yang telah ditetapkan dan tidak bertentangan dengan ketertiban umum, kesusilaan, dan undang-undang negara, maka dapat diberikan paten. Dalam sistem ini tidak diselidiki kesamaan penemuan yang dimiliki dengan penemuan sebelumnya. Namun, apabila kemudian diketahui ada kesamaan yang berarti paten tersebut tidak baru, maka akan menjadi dasar pembatalan paten di pengadilan. Lihat: Adrian Sutedi, Hak Atas Kekayaan Intelektual (Jakarta: Sinar Grafika, 2013), hlm. 68.

8 Endang Purwaningsih, Seri Hukum Kekayaan Intelektual Hukum Paten (Bandung: Mandar Maju, 2015), hlm. 1.

9 Basuki Antariksa, "Landasan Filosofis dan Sejarah Perkembangan Perlindungan Hak Kekayaan Intelektual: Relevansinya Bagi Kepentingan Pembangunan di Indonesia”, Jurnal Ekonomi Kreatif, 1, 1 (2012), hlm. 16. 


\section{Hak dan Kewajiban Pemilik atau Pemegang Paten}

Hak dan kewajiban pemilik atau pemegang paten diatur dalam Pasal 19 hingga Pasal 21 UU Paten Tahun 2016. Menurut Pasal 19 UU Paten Tahun 2016, pemegang paten memiliki hak eksklusif untuk melaksanakan paten yang dimilikinya dan untuk melarang pihak lain yang tanpa persetujuannya. Pemegang paten memiliki hak penuh terhadap penguasaan terhadap paten dalam hal penguasaan paten tersebut. Dalam hal paten-produk, pemegang paten berhak untuk membuat, menggunakan, menjual, mengimpor, menyewakan, menyerahkan, atau menyediakan untuk dijual atau disewakan atau diserahkan produk yang diberi paten. Sedangkan dalam hal paten-proses, pemegang paten berhak untuk menggunakan proses produksi yang diberi paten untuk membuat barang atau tindakan lainnya sebagaimana paten-produk. ${ }^{10}$ Perbuatan-perbuatan dalam hak eksklusif tersebut berarti meliputi produksi barang dari yang dipatenkan (manufacturing), penggunaan (using) dan penjualan (selling) dari barang tersebut, dan lain-lain perbuatan yang berkaitan dengan penjualan barang itu seperti mengimpor dan menyimpan (stocking). ${ }^{11}$ Jika diringkas, hak eksklusif yang demikian itu meliputi kegiatan produksi dan juga komersialisasinya. ${ }^{12}$

Dalam penjelasan UU Paten Tahun 2016 disebutkan, hak eksklusif adalah hak yang hanya diberikan kepada pemegang paten untuk jangka waktu tertentu guna melaksanakan sendiri secara komersial atau memberikan hak lebih lanjut untuk itu kepada orang lain. Dengan demikian, orang lain dilarang melaksanakan paten tersebut tanpa persetujuan pemegang paten. Sedangkan yang dimaksud dengan produk mencakup alat, mesin, komposisi, formula, product by process, sistem, dan lain-lain.

10 Syahrial, "Aspek Hukum Pendaftaran Hak Cipta dan Paten”, Greget: Jurnal Pengetahuan dan Penciptaan Tari, 13, 1 (2014), hlm. 95.

11 Tony Hanoraga dan Niken Prasetyawati, "Lisensi Wajib Sebagai Salah Satu Wujud Pembatasan Hak Eksklusif Paten”, Jurnal Sosial Humaniora, 8, 2 (2015), hlm. 173.

12 M. Zulfa Aulia, "Perlindungan Hukum Ekspresi Kreatif Manusia: Telaah terhadap Perlindungan Hak Kekayaan Intelektual dan Ekspresi Budaya Tradisional”, Jurnal Hukum Ius Quia Iustum, 14, 3 (2007), hlm. 362. 
Oleh karena hak eksklusif hanya diberikan kepada inventor atau pemegang paten, maka pihak lain menjadi tertutup untuk turut menggunakan karya atau invensi tersebut, terkecuali penggunaannya masih dalam kepentingan pendidikan, penelitian, dan tidak komersil. Namun, jika penggunaannya dalam wilayah komersil, ia baru diperbolehkan setelah mendapatkan izin terlebih dahulu dari pemilik haknya. ${ }^{13}$

Sebagai imbangan atas hak yang diperoleh, pemegang paten juga memiliki kewajiban, yaitu membuat produk atau menggunakan proses di Indonesia. Hal ini dimaksudkan untuk menunjang transfer teknologi, penyerapan investasi dan/atau penyediaan lapangan kerja. Bagi pemegang paten dari luar negeri yang mendaftarkan invensinya di Indonesia, maka ia wajib membuat atau mengembangkan penemuannya tersebut di Indonesia. Pemegang paten juga memiliki kewajiban untuk membayar biaya tahunan. Biaya tahunan (annual fee) adalah biaya yang harus dibayarkan oleh pemegang paten secara teratur untuk setiap tahun. Istilah ini dikenal juga di beberapa negara sebagai biaya pemeliharaan (maintenance fee) ${ }^{14}$

Adanya imbangan antara hak dan kewajiban tersebut sejalan dengan fungsi utama paten, yang menurut A. Chandrawulan dan Huala Adolf ada dua. Pertama, memberi kesempatan bagi kembalinya investasi yang telah dikeluarkan untuk penelitian dan pengembangan dan di dalam produksi dengan memberikan suatu kedudukan eksklusif untuk jangka waktu tertentu. Kedua, guna mendorong penyebarluasan teknologi baru secara layak dan wajar. ${ }^{15}$

\section{Perkembangan Penghapusan Paten}

Terdapat perbedaan terkait istilah penghapusan, sebagaimana yang digunakan dalam judul artikel ini. Secara yuridis dalam UU Paten

13 Aulia, "Perlindungan Hukum Ekspresi Kreatif Manusia”, hlm. 362.

14 Biaya Pemeliharaan paten atau biaya tahunan paten yaitu biaya yang dibebankan kepada pemegang paten yang terhitung selama jangka waktu perlindungan paten berlangsung. Biaya tersebut merupakan salah satu bentuk penerimaan negara bukan pajak.

15 A. Chandrawulan dan Huala Adolf, Aspek-aspek Hukum tentang Paten”, Jurnal Hukum dan Pembangunan, 20, 4 (1990), hlm. 313. 
Tahun 2016, istilah yang digunakan adalah penghapusan, sedangkan dalam UU Paten sebelumnya (UU No. 14 Tahun 2001) digunakan istilah pembatalan. Terkait perbedaan istilah ini, sesungguhnya tidak terdapat perbedaan yang mendasar, kecuali hanya soal pilihan kata. Pada UU Paten Tahun 2001, ketentuan pembatalan diklasifikasikan menjadi tiga macam, yaitu "batal demi hukum", "batal karena permohonan", dan "batal atas gugatan". Batal demi hukum mengandung maksud paten batal akibat pemegang paten tidak membayar biaya tahun atau biaya pemeliharaan paten; batal karena permohonan pemegang Paten berarti pemegang paten meminta kepada negara (menteri) untuk membatalkan paten yang sudah diterima; batal karena gugatan berarti pembatalan yang dilakukan oleh Pengadilan Niaga yang memiliki kekuatan hukum yang tetap.

Dalam UU Paten Tahun 2016, istilah pembatalan diubah menjadi penghapusan. Dalam UU ini, penghapusan paten diklasifikasikan ke dalam empat macam, yaitu "penghapusan karena permohonan pemegang paten", "penghapusan akibat putusan komisi banding paten", "penghapusan akibat putusan pengadilan niaga yang telah memiliki kekuatan yang tetap", dan "pembatalan dikarenakan pemegang paten tidak memenuhi kewajiban membayar biaya tahunan paten". Penghapusan paten dengan alasan "permohonan penghapusan" dilakukan berdasarkan permohonan secara tertulis yang diajukan oleh pemegang paten terhadap seluruh atau sebagian klaim kepada Menteri. Dalam hal permohonan penghapusan sebagian klaim, sebagian klaim disesuaikan dengan tidak memperluas ruang lingkup klaim dimaksud. Penghapusan paten tidak dapat dilakukan jika penerima lisensi tidak memberikan persetujuan secara tertulis yang dilampirkan pada permohonan penghapusan paten.

Penghapusan paten berdasarkan "putusan pengadilan yang telah mempunyai kekuatan hukum tetap" dilakukan jika:

1. Paten yang diajukan permohonan seharusnya tidak diberikan;

2. Paten yang berasal dari sumber daya genetik dan/atau pengetahuan tradisional tidak disebutkan dengan jelas dan benar asal sumber daya genetik dan/atau pengetahuan tradisional tersebut dalam deskripsi; 
3. Paten dimaksud sama dengan paten lain yang telah diberikan pihak lain untuk invensi yang sama;

4. Pemberian lisensi-wajib ternyata tidak mampu mencegah berlangsungnya pelaksanaan paten dalam bentuk dan cara yang merugikan kepentingan masyarakat dalam waktu dua tahun sejak tanggal pemberian lisensi-wajib yang bersangkutan atau sejak tanggal pemberian lisensi-wajib pertama dalam hal diberikan beberapa lisensi-wajib;

5. Pemegang paten tidak membuat produk atau menggunakan proses di Indonesia yang menunjang transfer teknologi, penyerapan investasi dan/atau penyediaan lapangan kerja.

Paten dapat dihapuskan berdasarkan "putusan komisi banding paten", jika pemegang paten tidak memenuhi kewajiban membayar biaya tahunan dalam jangka waktu enam bulan terhitung sejak tanggal sertifikat paten diterbitkan. Menteri wajib memberitahukan kepada pemegang paten dalam jangka waktu 30 hari sebelum paten dimaksud dinyatakan hapus karena tidak membayar biaya tahunan paten. Paten juga dapat dihapuskan karena "pemegang paten tidak membayar biaya tahunan paten”, hal ini berlaku dalam jangka waktu yang telah ditentukan sebagaimana tercantum dalam Pasal 126 UU Paten Tahun 2016, yaitu:

1. Pembayaran biaya tahunan wajib dilakukan paling lambat enam bulan terhitung sejak tanggal sertifikat paten diterbitkan;

2. Biaya tahunan dibayarkan untuk satu tahun pertama sejak tanggal penerimaan sampai dengan tahun diberi paten ditambah biaya tahunan satu tahun berikutnya;

3. Pembayaran biaya tahunan selanjutnya dilakukan paling lama satu bulan sebelum tanggal yang sama dengan tanggal penerimaan pada periode masa perlindungan tahun berikutnya.

Terhadap paten yang dinyatakan dihapus, maka menteri memberitahukan secara tertulis dalam bentuk elektronik atau non-elektronik kepada pemegang paten atau kuasanya dan penerima lisensi atau kuasanya. Paten yang dinyatakan dihapus selanjutnya dicatat dan diumumkan. Pemegang paten atau penerima lisensi yang dinyatakan hapus tidak dikenai kewajiban membayar biaya tahunan. 
Penghapusan paten menghilangkan segala akibat hukum yang berkaitan dengan paten dan hal lain yang berasal dari paten yang dimaksud. Hak eksklusif pemegang paten hilang sejak keputusan pengadilan niaga yang mempunyai kekuatan hukum yang tetap menghapuskan paten yang dimiliki pemegang paten.

Paten yang telah dihapus mengakibatkan pemegang paten tidak lagi memiliki kewajiban untuk membayar biaya tahunan paten, sehingga ia tidak dapat mendapatkan perlindungan akan paten yang sebelumnya dimiliki. Selain itu, penghapusan juga menghilangkan segala akibat hukum yang berkaitan dengan paten. ${ }^{16}$ Berdasarkan Pasal 141 UU Paten Tahun 2016, paten yang telah dihapus tidak dapat dihidupkan kembali, kecuali berdasarkan putusan pengadilan. Paten yang dinyatakan dihapus dan telah memiliki kekuatan hukum yang tetap akan menjadikan paten tersebut menjadi public domain.

Menurut Erik Saropie dari Bagian Pelayanan Teknis Direktorat Paten, paten dapat dihapus dengan cara permintaan atau permohonan dari pemegang paten itu sendiri, yang disebabkan oleh dua faktor, pertama, alasan penemuan/invensi tersebut dinilai tidak menghasilkan nilai ekonomi ataupun royalti dari penggunaannya dan perkembangan industri sudah tidak lagi membutuhkan invensi yang mereka dapatkan. Hal ini biasanya dikarenakan adanya penyempurnaan ataupun invensi yang dinilai lebih baru dan efisien. Kedua, dikarenakan berakhirnya kerjasama antara inventor yang berkolaborasi dengan beberapa inventor lain yang membentuk kelompok inventor, namun invensi tersebut tidak dapat dilanjutkan lagi dikarenakan inventor utama sudah tidak bisa melanjutkan invensi tersebut. ${ }^{17}$

Sedangkan menurut Fadli Rahman dari Bagian Sertifikasi, Pemeliharaan, Mutasi dan Lisensi pada Diretorat Paten, beberapa penghapusan disebabkan adanya cacat hukum, artinya paten yang

16 https: / / www.hukumonline.com/berita/baca/lt57aebff434001/inimekanisme-penghapusan-hak-paten, "Ini Mekanisme Penghapusan Paten", diakses 14/3/2019.

17 Wawancara dengan Erik Saropie, Seksi Palayanan Teknis Paten Direktorat Jenderal Kekayaan Intelektual, 25/3/2019. 
dimiliki oleh inventor diklaim oleh orang lain sehingga paten tersebut berdasarkan putusan pengadilan dapat dihapuskan. Penghapusan paten mengakibatkan terhapusnya paten dari daftar umum paten. Selain itu terkait pemberian lisensi-wajib yang tidak dapat mencegahnya untuk dilakukan atau dilaksanakan paten juga dapat mengakibatkan paten tersebut dihapus. Paten yang dihapus pada Direktorat Kekayaan Intelektual umumnya didominasi oleh paten. ${ }^{18}$

Oleh karena dalam UU Paten sebelumnya (Tahun 2001) digunakan istilah pembatalan untuk istilah penghapusan yang digunakan dalam UU Paten sekarang (Tahun 2016), maka data yang ditampilkan berikut, sesuai dengan sumber di Direktorat Jenderal Kekayaan Intelektual, sebagiannya masih menggunakan istilah pembatalan. Dalam tahun 2014-2016, jumlah pembatalan paten akibat batal demi hukum $(\mathrm{BDH})$ oleh Direktorat Jenderal Kekayaan Intelektual Kementerian Hukum dan Hak Asasi Manusia terlihat dalam tabel 1.

Tabel 1. Pembatalan paten (batal demi hukum) 2014-2016

\begin{tabular}{cccc}
\hline \multirow{2}{*}{ Tahun } & \multicolumn{3}{c}{ Paten } \\
\cline { 2 - 3 } & Dalam Negeri & Jumlah \\
\hline 2014 & 43 & 5263 & 5306 \\
\hline 2015 & 24 & 2561 & 2485 \\
\hline 2016 & 565 & 797 & 1362 \\
\hline Jumlah & $\mathbf{6 3 2}$ & $\mathbf{8 6 2 1}$ & $\mathbf{9 1 5 3}$ \\
\hline
\end{tabular}

Sumber: Direktorat Jenderal Kekayaan Intelektual

Data dalam tabel 1 memperlihatkan pada tahun 2014 terdapat 5306 paten yang dibatalkan, dengan rincian ada 43 paten dalam negeri dan 5263 dari luar negeri. Pada tahun 2015, paten yang dibatalkan sebanyak 2485, dengan rincian 24 dari dalam negeri dan 2561 dari luar negeri. Pada tahun 2016, ada sejumlah berjumlah 1362 paten yang dibatalkan, dengan rincian 565 dari dalam negeri dan 797 dari luar negeri. Data-data ini menunjukkan, jumlah paten yang dibatalkan dari dalam dan luar negeri sesungguhnya seimbang, sekalipun

18 Wawancara dengan Fadli Rahman, Subdit Sertifikasi, Pemeliharaan, Mutasi dan Litigasi Paten Direktorat Jenderal Kekayaan Intelektual, 25 / 3 / 2019. 
dari jumlah paten yang diterima (granted) sebenarnya sangat besar selisihnya.

Data terkait paten yang dibatalkan tersebut apabila hendak dibedakan antara paten dan paten sederhana, maka akan terlihat pada tabel 2. Dalam kurun waktu tahun 2014-2016, jumlah pembatalan untuk paten lebih banyak ketimbang paten sederhana. Hal ini bisa jadi disebabkan karena invensi pada paten sederhana terkait dengan produk atau alat-alat yang sifatnya praktis, sehingga lebih aplikatif ketimbang paten. Tabel 2 juga memberitahu bahwa kecenderungan pembatalan paten dalam kurun tiga tahun tersebut semakin besar. Jika pada tahun 2014 ada 43 pembatalan, dan 2015 menurun menjadi 24, namun pada tahun 2016 meningkat tajam menjadi 565.

Tabel 2. Pembatalan paten (batal demi hukum) dalam negeri 2014-2016

\begin{tabular}{cccc}
\hline Tahun & Paten & Paten Sederhana & Jumlah \\
\hline 2014 & 24 & 19 & 43 \\
\hline 2015 & 15 & 9 & 24 \\
\hline 2016 & 341 & 224 & 565 \\
\hline Jumlah & $\mathbf{3 8 0}$ & $\mathbf{2 5 2}$ & $\mathbf{6 3 2}$ \\
\hline
\end{tabular}

Sumber: Direktorat Jenderal Kekayaan Intelektual

Keadaan serupa juga terjadi dalam pembatalan paten luar negeri selama kurun waktu 2014-2016. Tabel 3 memperlihatkan jumlah pembatalan paten jauh lebih banyak ketimbang paten sederhana. Secara keseluruhan dalam kurun tiga tahun 2014-2016, paten yang batal demi hukum berjumlah 8596, sedangkan paten sederhana

Tabel 3. Pembatalan paten (batal demi hukum) luar negeri 2014-2016

\begin{tabular}{cccc}
\hline Tahun & Paten & Paten Sederhana & Jumlah \\
\hline 2014 & 5253 & 10 & 5263 \\
\hline 2015 & 2551 & 10 & 2561 \\
\hline 2016 & 792 & 5 & 797 \\
\hline Jumlah & $\mathbf{8 5 9 6}$ & $\mathbf{2 5}$ & $\mathbf{8 6 2 1}$ \\
\hline
\end{tabular}

Sumber: Direktorat Jenderal Kekayaan Intelektual 
ada 25. Namun kebalikan dengan pembatalan paten di Indonesia, pada pembatalan paten dari luar negeri justru menunjukkan kecenderungan semakin menurun. Jika tahun 2014 ada pembatalan untuk 5263, maka tahun 2015 menurun menjadi 2561 dan tahun 2016 semakin menurun menjadi 797.

Sejak diberlakukannya UU Paten Tahun 2016, istilah "pembatalan paten" diubah menjadi "penghapusan paten". Oleh karena perubahan ini hanya soal istilah, maka paten yang kemudian diberi status "dihapus" juga tidak berubah secara drastis. Jumlah paten dari luar negeri yang dihapuskan tetap lebih besar ketimbang paten dari dalam negeri. Sekali lagi hal ini karena memang jumlah paten yang diberi (granted) dari luar negeri juga jauh lebih besar ketimbang paten dalam negeri. Data tentang penghapusan paten tersebut dapat dilihat pada tabel 4 .

Tabel 4. Penghapusan paten 2017-2018

\begin{tabular}{cccc}
\hline \multirow{2}{*}{ Tahun } & \multicolumn{3}{c}{ Paten } \\
\cline { 2 - 3 } & Dalam Negeri & Lumlah Negeri & \\
\hline 2017 & 22 & 964 & 986 \\
\hline 2018 & 16 & 3544 & 3560 \\
\hline Jumlah & $\mathbf{3 8}$ & $\mathbf{4 5 0 8}$ & $\mathbf{4 5 4 6}$ \\
\hline
\end{tabular}

Sumber: Direktorat Jenderal Kekayaan Intelektual

Tabel 4 juga menunjukkan, secara keseluruhan penghapusan paten dalam negeri maupun paten dari luar negeri dalam kurun tahun 2017-2018 berjumlah 4546. Paten dalam negeri yang dihapuskan relatif menurun dalam dua tahun tersebut. Hal ini berbanding terbalik dengan penghapusan paten dari luar negeri, yang justru relatif meningkat.

Secara keseluruhan penghapusan paten dalam tahun 2017-2018 mengalami peningkatan. Perlu dipahami, penghapusan paten dalam dua tahun tersebut merupakan paten yang telah diberi (granted), dan umumnya berlaku sesuai dan menurut ketentuan UU Paten Tahun 2001, sementara penghapusan didasarkan pada UU Paten Tahun 2016. Ini berarti tahun-tahun tersebut merupakan tahun peralihan 
antara dua UU Paten. Terkait dengan peralihan dari pembatalan ke penghapusan tersebut, Krisman Tarigan dari Subdit Penyusun Tindak Lanjut Laporan Paten Direktorat Jenderal Kekayaan Intelektual mengatakan:

"Antara peralihan UU No. 14 Tahun 2001 ke UU No. 13 Tahun 2016 yang diundangkan pada tanggal 26 Agustus 2016, ada masa transisi. Dengan adanya UU No. 13 Tahun 2016 sebelumnya telah diatur melalui surat edaran ditjen untuk melakukan pembayaran yang terlambat dalam dua tahun sebelum UU No. 13 Tahun 2016. Jadi melalui surat edaran ditjen tersebut, Ditjen KI memberikan izin atau dispensasi bagi pemegang paten yang terlambat untuk membayar paten tersebut dalam kurun waktu bulan Agustus-Desember 2016 yang masih tertunggak. Jadi, per 1 Januari 2017, bagi pemegang paten yang tidak membayar selama periode sebelumnya tersebut akan diberikan status "penghapusan" pada patennya". ${ }^{19}$

Dengan begitu, peralihan terkait tempo waktu pembayaran biaya tahunan paten yang pada awalnya akan dihapus apabila pemegang paten tidak melakukan pembayaran selama tiga tahun berturutturut, kini menjadi pertahunnya. Oleh karena itu, Direktorat Jenderal Kekayaan Intelektual mengeluarkan Surat Edaran Nomor HKI-308-OT.02.02 Tahun 2016 tentang Masa Peralihan Biaya Tahunan Undang-Undang Paten Nomor 14 Tahun 2001 ke Undang-Undang Nomor 13 Tahun 2016.

\section{E. Penyebab Penghapusan Paten}

Setiap pemegang paten memiliki tanggung jawab ataupun kewajiban pada patennya. Dalam hal ini pemegang paten diberi tanggung jawab terhadap pelaksanaan patennya sendiri. Apabila pemegang paten tidak dapat memenuhi salah satu tanggung jawab tersebut, maka pemegang paten akan menerima konskeunsi paten yang dimiliki atau dipegang dapat dibatalkan atau dihapuskan. Menurut Krisman, beberapa faktor yang menyebabkan penghapusan paten yang umumnya terjadi di Indonesia adalah:

1. Pemegang paten yang tidak melaksanakan pembiayaan tahunan paten;

19 Wawancara dengan Krisman Tarigan, Subdit Penyusun Tindak Lanjut Laporan Paten Direktorat Jenderal Kekayaan Intelektual, 25 / 3/2019. 
2. Pemegang paten yang tidak bisa memaksimalkan patennya untuk dilaksanakan;

3. Pemegang paten yang tidak membuat atau melaksanakan patennya di Indonesia dan juga tidak meminta penangguhan akan paten yang didaftarkan untuk mengembangkan patennya di Indonesia;

4. Prosedur paten yang bertentangan dengan peraturan perundangundangan dan ketertiban umum, sehingga paten tersebut dihapuskan melalui Komisi Banding Paten dan/atau di Pengadilan Niaga; dan

5. Sengketa mengenai paten terkait klaim kepemilikan invensi pada paten tersebut yang diputus melalui Pengadilan Niaga.

Dari beberapa faktor tersebut, penghapusan paten didominasi akibat pemegang paten yang tidak melakukan pembayaran biaya tahunan paten. Menurut Andi Kurniawan, alasan tidak dilakukannya pembayaran biaya tahunan dari pemegang paten umumnya adalah:

"Pada dasarnya tidak membayar biaya tahunan (annual fee) bukan hanya karena kendala biaya oleh pemegang paten, hal yang lain mempengaruhi yaitu mengingat pada saat melakukan invensi di bidang paten juga membutuhkan riset yang memakan biaya yang cukup besar, kemudian paten tersebut tidak memiliki nilai ekonomis, sehingga paten tersebut tidak memberikan keuntungan ataupun manfaat yang dihasilkan dari industri tertentu" ${ }^{20}$

Senada dengan Krisman Tarigan dan Fadli Rahman, bahwa paten baik pembatalan ataupun penghapusan paten didominasi penghapusan umumnya karena pemegang paten tidak membayar biaya tahunan (annual fee). Hal demikian dikarenakan ada dua faktor, yaitu pertama, pemegang paten yang tidak membayarbiaya tahunan dengan alasan paten tersebut sudah tidak memiliki nilai ekonomis, sehingga paten tersebut sedikit bahkan tidak memberikan keuntungan bagi perkembangan industri. Hal ini dikarenakan paten merupakan benda yang tidak berwujud yang dikategorikan sebagai aktiva tidak berwujud, sehingga paten memiliki umur pada nilai jual pada per tahunnya yang akan dihitung jumlah keuntungannya, di mana nilai aset tak

20 Wawancara dengan Andi Kurniawan, Subdit Pelayanan Hukum Paten Direktorat Jenderal Kekayaan Intelektual, 25/3/2019. 
berwujud seperti paten akan memiliki nilai penyusutan pada periode tertentu. Kedua, biaya riset pengembangan paten yang memerlukan biaya yang cukup besar sehingga memengaruhi akumulasi terhadap biaya tahunan tersebut. Alasan penghapusan juga sisanya karena permohonan dari pemegang paten itu sendiri dan penghapusan paten karena putusan Pengadilan Niaga sangat kecil.

Khusus bagi penghapusan paten dalam negeri, faktor yang mempengaruhi penghapusan dalam kurun dua tahun terakhir juga terlihat dari beberapa pemegang paten tidak mengetahui dan/atau kurangnya pemahaman mengenai masa peralihan atau transisi dalam pembayaran biaya tahunan dari UU Paten yang lama (2001) ke UU Paten baru (2016).

Oleh karena itu, Ditjen KI melalui Direktorat Paten melakukan pemberitahuan mengenai Surat Edaran Peralihan Biaya tahunan tesebut melalui website resmi Direktorat Jenderal Kekayaan Intelektual. Adapun pemberitahuan secara langsung diberikan sebanyak tiga kali sebelum jatuh tempo kepada setiap pemegang paten untuk melakukan pembayaran biaya tahunan. Pemberitahuan tersebut ditujukan langsung kepada pemegang paten bersangkutan ataupun kepada Konsultan Kekayaan Intelektual sebagai pihak ketiga yang mengurus pengurusan paten bagi pemegang paten yang berdomisili di luar negeri.

Adapun kendala lain bagi pemegang paten di Indonesia yang tidak mampu membayar kewajibannya yaitu biaya pemeliharaan paten yang dinilai cukup besar, selain dari beberapa pengembangan riset yang banyak memakan biaya, terutama bagi beberapa pemegang paten dari beberapa kalangan institusi pendidikan seperti dari Lembaga Penelitian dan Pengabdian Masyarakat (LPPM) pada beberapa universitas atau perguruan tinggi di Indonesia. Kemudian pengembangan riset itu dilihat dari akumulasi jumlah klaim pada paten yang akan dilindungi. Hal ini juga didasarkan pada perubahan jumlah tarif pembayaran biaya tahunan yang ditetapkan berdasarkan pada Penerimaan Negara Bukan Pajak (PNBP) Kemenkumham yang diatur melalui Peraturan Pemerintah.

Penghapusan paten mengakibatkan hilangnya status hak paten 
yang dimiliki oleh pemegang paten, selain itu juga berdampak pada pengalihan lisensi yang diberikan oleh pemegang paten kepada pihak ketiga sebagai penerima lisensi. Dalam hal keadaan paten tersebut dihapuskan, maka hak dan kewajiban bagi penerima lisensi untuk menggunakan atau memakai paten tersebut akan ikut terhapus. Hal ini juga berlaku bagi pemegang lisensi-wajib. Dalam hal pemberian lisensi wajib diberikan atas dasar permohonan kepada menteri untuk melaksanakan paten, paten tersebut adalah paten yang tidak dapat dilaksanakan selama jangka waktu tiga tahun berturut-turut sejak paten tersebut diberikan, dengan syarat ia mampu melaksanakan paten tersebut. Maka pemerintah memberikan lisensi wajib kepada pemohon untuk dapat dilaksanakan kembali. Apabila pemberian lisensi wajib ternyata tidak mampu dilaksanakan, maka paten tersebut dapat dihapuskan dan dijadikan sebagai public domain atau dapat digunakan oleh masyarakat secara umum.

Hakeksklusif dalamhakkekayaanintelektualdibatasiolehadanya jangka waktu perlindungan tertentu, di mana setiap perlindungan yang memiliki batasan jangka waktu itu akan berkahir, sehingga karya yang dihasilkan dalam hal ini paten yang semula dimiliki secara eksklusif oleh inventor tersebut akan menjadi milik umum. Dengan demikian, hasil karya invensi tersebut akan dapat digunakan oleh siapa pun tanpa adanya kewajiban untuk meminta izin terlebih dahulu kepada inventornya. Hal ini bisa disebut dengan public domain. Dengan adanya public domain, hal tersebut memberikan kesempatan seluas-luasnya kepada masyarakat yang hendak mempergunakan hasil karya tersebut untuk dilakukan sebagai pengembangan dan membentuk inovasi baru dari penemuan yang telah ada sebelumnya. Selain itu, public domain memberikan manfaat untuk mengendalikan penggunaan hasil penemuan sebagai kebutuhan yang harus dipenuhi dalam perkembangan masyarakat, sehingga memberikan pengaruh dan manfaat di dalam masyarakat.

\section{F. Kesimpulan}

Berdasarkan penelitian dan pembahasan dapat disimpulkan, pertama, 
pembatalan paten atau penghapusan paten yang terdaftar di Indonesia didominasi dalam bentuk paten dan bukan paten sederhana, dan mayoritas paten yang dibatalkan atau dihapuskan berasal dari luar negeri. Namun demikian fakta ini tidak berarti bahwa paten dalam negeri jauh lebih aplikatif atau lebih mematuhi ketentuan peraturan perundang-undangan, melainkan juga harus dikaitkan bahwa jumlah paten terdaftar di Indonesia sejauh ini memang sebagian besar berasal dari luar negeri. Begitu pula soal pembatalan paten yang jauh lebih banyak ketimbang paten sederhana, bisa jadi memang disebabkan oleh paten sederhana melindungi invensiinvensi yang lebih praksis sehingga implementatif, tetapi juga harus dikaitkan bahwa jumlah paten terdaftar memang jauh lebih banyak ketimbang paten sederhana. Fakta lain terkait dengan pembatalan atau penghapusan paten ialah, jumlah paten yang dibatalkan atau dihapuskan sangat fluktuatif pertahunnya, baik yang berasal dari dalam maupun luar negeri, sehingga kadang mengarah pada penurunan tapi juga kadang peningkatan. Kedua, pembatalan atau penghapusan paten disebabkan oleh tidak dilakukannya pembayaran biaya pemeliharaan atau biaya tahunan. Hal ini dikarenakan hasil penemuan atau invensi paten yang dihasilkan tidak lagi memiliki nilai ekonomis dan memiliki keuntungan, sehingga penemuannya tersebut tidak dapat diterapkan di dalam industri; pemegang paten dalam melakukan penelitian membutuhkan biaya yang cukup besar, sehingga mempengaruhi akumulasi terhadap biaya pemeliharaan tersebut; dan beberapa pemegang paten terutama dari dalam negeri tidak mengetahui atau memahami masa peralihan atau transisi mengenai biaya pemeliharaan paten dari UU Paten lama (2001) ke UU Paten baru (2016), yang keduanya memang berbeda dalam menolerir tidak dibayarkannya biaya tahunan. Dalam UU lama, paten bisa batal jika tidak dibayar selama tiga tahun berturut-turut, sedangkan dalam UU baru akan dihapus jika tidak dibayar setiap tahunnya. 


\section{Daftar Pustaka}

\section{Artikel/Buku/Laporan}

Antariksa, Basuki. "Landasan Filosofis dan Sejarah Perkembangan Perlindungan Hak Kekayaan Intelektual: Relevansinya Bagi Kepentingan Pembangunan di Indonesia”. Jurnal Ekonomi Kreatif, 1, 1 (2012): 1-21.

Aulia, M. Zulfa. "Perlindungan Hukum Ekspresi Kreatif Manusia: Telaah terhadap Perlindungan Hak Kekayaan Intelektual dan Ekspresi Budaya Tradisional”. Jurnal Hukum Ius Quia Iustum, 14, 3 (2007): 359-372.

Aulia, M.Zulfa. "Politik Hukum Pembentukan UU Paten di Indonesia: Industrialisasi, Liberalisasi, dan Harmonisasi”. Jurnal Hukum Ius Quia Iustum, 22, 2 (2015): 223-237. DOI: 10.20885 / iustum.vol22. iss2.art3

Chandrawulan, A. dan Huala Adolf, Aspek-aspek Hukum tentang Paten”. Jurnal Hukum dan Pembangunan, 20, 4 (1990): 312-328. DOI: 10.21143 /jhp.vol20.no4.906

Djumhana, Muhammad dan R. Djubaedillah. Hak Milik Intelektual: Sejarah, Teori, dan Prakteknya di Indonesia. Bandung: Citra Aditya Bakti, 1997.

Hanoraga, Tony dan Niken Prasetyawati. "Lisensi Wajib Sebagai Salah Satu Wujud Pembatasan Hak Eksklusif Paten”. Jurnal Sosial Humaniora, 8, 2 (2015): 160-180. DOI: 10.12962/j24433527. v8i2.1250

https: / / www.hukumonline.com/berita/baca/1t57aebff434001/inimekanisme-penghapusan-hak-paten. "Ini Mekanisme Penghapusan Paten”. Diakses 14/3/2019.

Khairandy, Ridwan. Hukum Alih Teknologi. Yogyakarta: Fakultas Hukum Universitas Islam Indonesia, 1995.

Purwaningsih, Endang. Seri Hukum Kekayaan Intelektual Hukum Paten. Bandung: Mandar Maju, 2015.

Rudyat, Charlie. Kamus Hukum. Yogyakarta: Pustaka Mahardika, 2016.

Sutedi, Adrian. Hak Atas Kekayaan Intelektual. Jakarta: Sinar Grafika, 
2013.

Syahrial. "Aspek Hukum Pendaftaran Hak Cipta dan Paten”. Greget:

Jurnal Pengetahuan dan Penciptaan Tari, 13, 1 (2014): 91-100.

Syamsudin, Dadan. "Hak Kekayaan Intelektual dan Manfaatnya Bagi

Lembaga Litbang”. http://sumberdaya.ristekdikti.go.id/wpcontent/ uploads/2016/11/Makalah-HKI-dadan.pdf. Diakses $10 / 6 / 2019$.

Usanti, Trisadini Prasastinah. "Lahirnya Hak Kebendaan”. Perspektif:

Kajian Masalah Hukum dan Pembangunan, 17, 1 (2012): 44-53.

DOI: 10.30742 / perspektif.v17i1.93

Yuswanto, Slamet. Memahami Paten. Keni Media, Bandung, 2017.

\section{Peraturan Hukum}

Republik Indonesia. Kitab Undang-Undang Hukum Perdata.

Republik Indonesia. Undang-Undang Nomor 14 Tahun 2001 tentang Paten. Lembaran Negara Republik Indonesia Tahun 2001 Nomor 109, Tambahan Lembaran Negara Republik Indonesia Tahun 2001 Nomor 4130.

Republik Indonesia. Undang-Undang Nomor 13 Tahun 2016 tentang Paten. Lembaran Negara Republik Indonesia Tahun 2016 Nomor 176, Tambahan Lembaran Negara Republik Indonesia Tahun 2016 Nomor 5922. 